\title{
Turist Güvenliğinin Risk Azaltma Davranışı, Tavsiye Ve Tekrar Ziyaret Etme Niyeti Üzerindeki Etkisi: İstanbul'u Ziyaret Eden İranlı Turistler Üzerine Bir Araştırma
}

\section{The Impact of Tourist Safety on Risk Reduction Behavior, Recommendation and Revisit Intention: A Case Study on Iranian Tourists in Istanbul}

\author{
Ayşe Nevin Sert ${ }^{a^{*}}$ \\ ${ }^{a}$ Dr. Öğretim Üyesi, Selçuk Üniversitesi, Beyşehir Ali Akkanat Turizm Fakültesi, Turizm İşletmeciliği Bölümü, Beyşehir-Konya /Türkiye \\ ORCID: 0000-0003-0751-9377
}

\section{MAKALE BILGİSI}

Makale Geçmişi:

Başvuru tarihi: 01 Şubat 2019

Düzeltme tarihi: 17 Şubat 2019

Kabul tarihi: 25 Şubat 2019

Anahtar Kelimeler:
Algılanan Güvenlik,
Risk Azaltma Davranışı,
Tekrar Ziyaret ve Tavsiye Etme Niyeti,
İstanbul

\section{ARTICLE INFO}

\section{Article history:}

Received 01 February 2019

Received in revised form 17 February 2019

Accepted 25 February 2019

\section{Keywords:}

Perceived Security,

Risk Reduction Behaviour,

Revisit and Recommendation Intention,

Istanbul
ÖZ

Turist güvenliği turizmin gelişimi açısından önemli bir kavramdır. Turistlerin güvenlik algıları ve bu algılardan kaynaklı davranışlarının anlaşılması gerekmektedir. Çalışmada İstanbul'a gelen İranlı turistlerin İstanbul ile ilgili güvenlik algıları ve bu algılara bağlı olarak oluşan risk azaltma davranışları incelenmiştir. Ekim-Kasım, 2018 tarihlerinde İstanbul'u ziyaret eden 389 İranlı turiste yüz yüze anket uygulanmıştır. Yapılan çalışmada algılanan güvenliğin risk azaltma davranışı, tavsiye etme ve tekrar ziyaret etme niyeti üzerinde etkili olduğu bulgulanmıştır. Risk azaltma davranışlarıyla ilgili olarak İranlı turistlerin özellikle potansiyel bir kurban durumuna düşebilecekleri durumlardan kaçındıkları ve çevrelerinde olup bitenlere karşı uyanık oldukları görülmüştür. Bekar, tatile yalnız çıkanlar, gelir seviyesi yüksek, 45-49 yaş aralığındaki kişilerin güvenlik algılarının yüksek olduğu tespit edilmiştir

\section{Giriş}

Turizm endüstrisi açısından dünyanın her yerinde güvenlik hayati bir önem taşımaktadır. Güvenlik, Türk Dil Kurumu'na göre (2018) "toplum yaşamında yasal düzenin aksamadan yürütülmesi, kişilerin korkusuzca yaşayabilme durumu" olarak tanımlanmıştır. Turistin güvenlik algısı ise bulunacağı veya bulunmakta olduğu bölgede mevcut olan risklerin kendisine yönelme olasılığına ilişkin kişisel değerlendirmesi neticesinde oluşmaktadır (Aras, 2017). Güvenlik, Maslow'un ihtiyaçlar hiyerarşisi teorisinde önerildiği gibi kişilerin temel ihtiyaçlarında fizyolojik ihtiyaçlardan sonra en yüksek ikinci ihtiyaçtır (Maslow, 1970). Güvenlik, turizm gelişimini sağlamak konusunda temel taşlardan biridir. Diğer tüm ekonomik faaliyetlerden çok, bir turizm destinasyonun başarısı veya başarısızlığı, ziyaretçiler için güvenli ortam sağlayabilmesine bağlıdır (UNWTO, 1996; Batra, 2008). Kisacası, Hall, Timothy ve Duval' in (2004) belirttiği gibi turist

\footnotetext{
* Sorumlu Yazar / Corresponding author e-posta: nevinsert@selcuk.edu.tr
} 
güvenliği turizmin ayrılmaz bir unsurudur. Ancak turistler, turist olmalarından kaynaklanan özelliklere bağlı olarak savunmasız oldukları söylenebilir (Batra, 2008). Özellikle yabancı turistler, kıyafetleri, görünüşleri ve ziyaret ettikleri yerler itibariyle fark edildikleri için kolay hedefler haline gelebilmektedirler. Aynı zamanda koşulların elverişsizliği ve zaman kısıtlılığı nedeniyle maruz kaldıkları suçu yetkili makamlara bildirme olasılıkları daha düşük olarak görülmektedir. Suç duyurusunda bulunsalar bile, farklı bir milletten olmaları dolayısıyla suçluyu teşhis etmeleri de zordur. Bununla birlikte suçlunun yakalanıp yargılanması durumunda bile turistin geri dönüp şahitlik yapma şans1 yok gibidir (Aktaş Polat ve Polat, 2014). Ayrıca farklı kültür, dil engelleri, evlerinden çok uzakta olmaları da (Khajuria ve Khanna, 2014) suç mağduru olma risklerini yükseltmektedir (Batra, 2008). Turistlerin maruz kalabileceği tehlikelerden bazıları, iç karışıklıklar, hırsızlık, gasp, yaralama, cinsel saldırı, terörizm, doğal afetler vb. gibi olaylardır. Bir destinasyonda yaşanabilecek söz konusu tehlikeler hem turistler hem de destinasyonları için ciddi sonuçlar doğurabilir (Ryan, 1993) ve destinasyona olan turizm talebinde sert düşüşler yaşanmasına yol açabilir (Seçilmiş ve Ünlüönen, 2009; George, 2010; Khajuria ve Khanna, 2014; Woosnam, Shafer, Scott ve Timothy, 2015).

Turizm ve güvenlik kavramları risk algısı, destinasyon imajı, terörizm, suç, motivasyon gibi çeşitli açılardan ele alınmıştır (Sönmez ve Graefe, 1998a, 1998b; Barker, Page ve Meyer, 2003; Hall vd., 2004; George, 2010; George ve Swart, 2012; Rittichainuwat ve Chakraborty, 2012; George ve Booyens, 2014; Seabra, Abrantes ve Kastenholz, 2014; Woosnam vd., 2015. Ancak çalışmalarda turistler tarafindan algılanan güvenlik ile turistlerin risk azaltıcı davranışlarının birlikte ele alındığı çalışma sayısı oldukça azdır. Oysa tüm turizm paydaşlarının, turistlerin güvenlik algılarını ve bu algılardan yola çıkarak gösterdikleri davranışları anlamaları gerekmektedir. Dolayısıyla bu çalışmanın dört temel amacı vardır. Birinci amaç güvenlik algısının risk azaltma davranışı üzerindeki etkisini ortaya koymaktır. İkinci amaç turistlerin güvenlik algısının tekrar ziyaret ve tavsiye etme niyeti üzerindeki etkisini araştırmaktır. Üçüncü amaç sosyodemografik özellikler ile güvenlik algısı ve risk azaltma tutumu-davranışı arasındaki ilişkiyi analiz etmektir. Dördüncü amaç ise, İstanbul'un İranlı turistler tarafindan güvenli bir destinasyon olarak algılanıp algılanmadığını belirlemektedir.

\section{Kavramsal Çerçeve}

Turizmin, destinasyonlar üzerinde önemli olumlu ve olumsuz ekonomik, çevresel ve sosyal etkileri olduğu bilinmektedir. İstenmeyen en önemli sosyal etkilerinden biri de kuşkusuz suçtur (George, 2010). Turizm doğası gereği, mal ve hizmetlerinin soyut olması ve deneyime dayanmasına bağlı olarak risklere, tehditlere ve suça açık bir hizmet endüstrisidir (Taşcı ve Gartner, 2007). Dolayısıyla güvenlik konuları, turistler ve turizm endüstrisi için büyük önem taşımaktadır.

Geçtiğimiz on y1l boyunca, güvenlik, turizm endüstrisinin karşılaştığ1 en önemli küresel sorunlardan biri olmuştur (Woosnam vd., 2015). Güvenlik, turizm büyümesi ve destinasyon rekabetçiliği açısından önemli bir faktör olarak görülmektedir. Ryan'a (1993) göre suç, destinasyonun doğası gereği kırılgan olan "güvenli" imajına ağır bir darbe indirerek bölgedeki turizmi azaltabilir hatta engelleyebilir. Bu nedenle turistlerin bir ülkeyi ziyaret ederken herhangi bir suça maruz kalmaması çok önemlidir. Ancak turistlerin "turist" olmaktan kaynaklı suç mağduru olma risklerinin yüksek olduğu aynı zamanda turistik bölgelerin de suç mahalli olma potansiyeline sahip olduğu söylenebilir (Barker vd., 2003). Diğer bir deyişle turistlerin ve turistik bölgelerin karakteristik özellikleri "dışarıdan gelen" turistleri daha görünür kılabilir ve alışılmadık bir ortam da kendilerini daha az güvende hissettirebilir. Turistler ayrıca dil zorlukları ile kısıtlanabilir ve bulundukları yer ve çevre ile ilgili sınırlı bilgiye sahip olabilirler. Sonuç olarak, turistler bilmedikleri bir ortamda yabancılarla etkileşim içinde olmaktadırlar ve bu da cinsel saldırı, yankesicilik, dolandırıcılık, gasp, kapkaç, çalıntı mal satma, kumarhane suçları, yaşlılığa bağlı suçlar, konaklama ve eğlence mekânlarında hırsızlıklar, terör eylemleri, toplu taşıma araçlarında saldırılar gibi suçlara mazur kalma risklerini artırmaktadır. (Barker vd., 2003; Monk, Heinonen, ve Eck, 2010; Aktaş Polat ve Polat, 2014; Rezaei vd., 2018).

Seyahat riskleri sadece suç olarak kendini göstermez aynı zamanda turizm mal ve hizmetlerin tüketiminden kaynaklı örneğin sağlık problemleri gibi "fiziksel riskler"; turistlerin paralarının karşılığını alamaması, para israfı, beklentilerinin karşılığını alamama durumu olan "finansal risk"; beklenilen işlevlerin yerine getirilememesi örneğin, hava, aşırı kalabalık, olası grevler, elverișsiz turistik tesisler, misafirperverlik göstermeyen çalışanlar, düşmanca tavır takınan yerel halk, kötü yiyecekler gibi olumsuzlukları içeren "performans riski", turistlerin risk alma tercihleriyle ilgili olan "sosyo-psikolojik" risk, son olarak da turistlerin zamanlarını boşa harcamaları ya da zaman kaybı olarak tarif edilen "zaman" riski de mevcuttur (Rezaei vd., 2018).

Risklerin algılanma biçimi güvenlik algısını şekillendirmektedir (George, 2010). Aras'ın (2017) belirttiği gibi turistin güvenlik algısı, bulunacağı veya bulunmakta olduğu bölgede mevcut olan risklerin kendisine yönelme olasılığına ilişkin kişisel değerlendirmesi neticesinde oluşur. Turistlerin güvenlik algıları ve bir suçun mağduru olma korkusu, turist davranışı üzerindeki etkisi bakımından suça maruz kalmak kadar önemli olup, algılanan risk turistin kabul edilebilir risk eşiğini aştığında, seyahat kararları üzerinde değişikliklere neden olabilir. (Barker vd., 2003). Irvine ve Anderson (2006), risk algısının turistlerin seyahat planlarını erteleme veya iptal etme davranışlarını etkilediğini tespit etmiştir. Demirci (2018), terörün İstanbul turizmine olan etkisini incelediği araştırmasında terörün korkusunun turist sayısında azalmaya yol açığını belirtmiştir.

Daha önce de belirtildiği gibi turizm, güvenlik kavramına koşulsuz bir biçimde bağlıdır. Turist davranışı ve sonuç olarak destinasyonlar, güvenlik algısı ve risk yönetimi tarafindan derinden etkilenmektedir (Hall vd., 2004). Turizm endüstrisinde güvenlik konusunun her geçen gün önem kazanması nedeniyle konuyla ilgili araştırmaların sayısında da artış gözlemlenmiştir (Hall vd., 2004). Yapılan çalışmalar genellikle algılanan risk (Sönmez ve Graefe, 1998b; Rezaei vd., 2018), güvenlik (Barker vd., 2003; George, 2003; Seçilmiş ve Ünlüönen 2009; Wichasin, ve Doungphummes, 2012; Rittichainuwat ve Chakraborty, 2012; Woosnam vd., 2015; Bayhan ve Ünlüönen, 2016; Aras, 2017), terörizm (Sönmez, Apostolopoulos ve Tarlow, 1999 Ryan, 2003; Yeşiltaş, Öztürk ve Türkmen, 2008; Seabra vd., 2014; Demirci, 2018), suç (Ryan, 2003; Schroeder ve Pennington- 
Gray, 2014), destinasyon imajı (Sönmez ve Sirakaya, 2002; Chew ve Jahari, 2014; Ateşoğlu ve Türker, 2014), motivasyon (Pearce ve Lee, 2005; Rezaei vd., 2018) üzerinde yoğunlaşmıştır. Yeşiltaş vd., (2008), ikincil kaynakları kullanarak terör ve turizm ilişkisini ortaya koymaya çalışmış ve Türkiye'de turizmin terörizmden en az etkilenmesini sağlamaya yönelik, imaj oluşturma, kriz yönetimi, medya yönetimi, paydaş işbirliği gibi konularda öneriler sunmuşlardır. Seçilmiş ve Ünlüönen (2009), İstanbul'u ziyaret eden yerli ve yabanı turistlerin güvenlik algılarını incelemişlerdir. Çalışmada konaklama açısından güvenli bulunan İstanbul toplu taşım araçları ve eğlence mekanları açısından güvensiz bulunmuştur. Aktaş Polat ve Polat (2014), turistlerin mağduru oldukları suç türü ile sosyo-demografik özellikler arasındaki ilişkiyi incelemiş olup, suç türünün turistlerin geldiği ülke ve ülkelerinin sahip olduğu kişi başına ortalama milli gelirlere göre farklılaştığını tespit etmişlerdir. Bayhan ve Ünlüönen (2016), Turist tercihlerinde güvenliğe ilişkin tutumlarının etkisi üzerine yaptıkları araştırmada, turistlerin güvenliğe verdiği önemin cinsiyete göre farklılaştığını, kadın turistlerin erkek turistlere göre güvenliğe daha fazla önem verdiklerini bulgulamışlardır. Aras (2017), yaptığı çalışmada Türkiye'de turizm güvenliği sorunlunu ele almış ve güvenlik hizmetlerinin "daha fazla görünürlük" sergileyerek sunulduğunda güvenlik algısına olumsuz etkide bulunacağını bu nedenle özgün güvenlik konseptlerinin geliştirilmesi gerektiğini belirmiştir. Turistlerin karşılaşacağ riskler ve güvenlikle ilgili yapılan çalışmalar krizlerle baş edebilmek veya turistlere daha güvenli bir ortam oluşturmak amacıyla paydaşlar tarafindan yapılan planlamalara dahil edilmesi açısından önem taşımaktadır (Woosnam vd., 2015).

Algılanan güvenliğin önemli bir sonucu da risk azaltma davranışlarını belirlemesidir (Baker vd., 2003). Risk azaltma davranışı öngörülen tehlikelere karşı turistlerin aldıkları kişisel önlemler olup, destinasyondan, bölgeden, belli bir merkezden uzak durmak (Sönmez ve Graefe, 1998a) veya kapsamlı bilgi arayışına girmek, fazla para taşımama, dikkat çekmemeye çalışmak vb. davranışlarla kendini göstermektedir. Risk azaltma davranışları turistlerin edinecekleri deneyimi ve tatilin kalitesini yakından etkilemektedir (Barker vd., 2003).

Güvenlik algısı risk azaltma davranışları yanında tavsiye etme ve tekrar ziyaret etme davranışını da etkilemektedir (Mansfeld ve Pizam, 2006; George, 2010; Woosnam vd., 2015). Kendilerini güvende hissetmeyen turistlerin destinasyonu tekrar ziyareti muhtemel değildir ve destinasyonu başkalarına tavsiye etmeleri olası değildir (Woosnam vd., 2015). Turizm endüstrisi güvenliği sağladığı ölçüde rağbet görecek ve gelişecektir (George ve Swart, 2012). Mansfeld ve Pizam'ın (2006) öne sürdüğü gibi, turistlerin emniyeti ve güvenliğini sağlamak için önlemler almak ve uygulamak turizm destinasyonun geleceği ve tekrar ziyareti açısından son derece önemlidir.

\section{Yöntem}

\subsection{Araştırma Modeli ve Hipotezler}

$\mathrm{Bu}$ çalışma turistler tarafından algılanan güvenliğin risk azaltma davranışı ile tavsiye etme ve tekrar ziyaret niyeti arasındaki ilişkiyi ve etkiyi belirlemeye yöneliktir. Bu doğrulta araştırma modeli Şekil 1.de gösterilmiştir.
Şekil 1. Araştırmanın Modeli

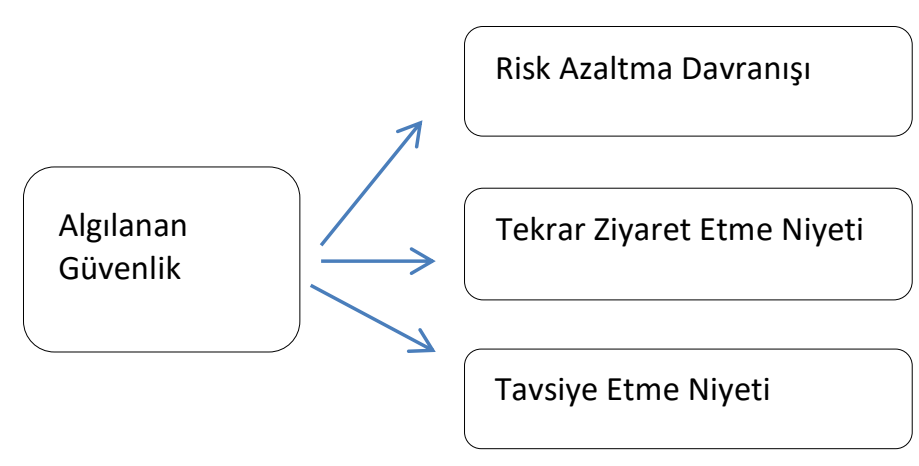

Yukarıda belirtilen kavramsak çerçeveden yola çıkarak aşağıdaki hipotezler oluşturulmuştur:

H1: Katılımcıların algıladıkları güvenlik risk azaltma davranışlarını etkilemektedir.

H2: Katılımcıların algıladıkları güvenlik tekrar ziyaret niyetlerini etkilemektedir.

H3: Katılımcıların algıladıkları güvenlik tavsiye etme niyetlerini etkilemektedir.

\subsection{Evren ve Örneklem}

Çalışmanın amacı doğrultusunda çalışma alanı olarak birçok milletten turistlerin y1l boyu ilgi gösterdiği İstanbul şehri ve İranlı turistler seçilmiştir. İstanbul binlerce y1llık bir geçmişe sahip Türkiye Cumhuriyeti'nin nüfus ve ekonomi bakımından en büyük merkezidir. İstanbul aynı zamanda başta Osmanlı olmak üzere geçmişten günümüze üzerinde yaşayan bütün medeniyetlerin izlerinin halâ görünür olduğu bir kültür şehri (İstanbul Kültür Çalıştayı, 2018) ve önemli bir turizm destinasyonudur. 2017 Temmuz ayı İstanbul turizmi istatistik raporlarına göre bir önceki yılın Temmuz ayına göre yabancı ziyaretçi sayısının \%43 oranında artış kaydettiği görülmüştür. Söz konusu raporda 2015 ve 2016 yıllarındaki menfur saldırılar ve aleyhte yürütülen kampanyalar neticesi gerileme eğilimine giren İstanbul turizminin 2017 Nisan ayı itibariyle yeniden yükselişe geçtiği ve Temmuz ayında rakamların yeniden 2015 yılı seviyesine yaklaştı̆̆ vurgulanmaktadır. 2016 yılının ilk 7 ayında 5.366.144 olan yabancı turist sayısı, 2017 Temmuz ayında 5.704.702 kişiye ulaşmıştır. Gelen turistlerde birinci sırada Almanlar (538.945 kişi), ikinci sırada ise İranlılar (427.018 kişi) yer almaktadır. Gelen İranlı turist sayısı her yıl artış göstermekte olup, 2010'da 272,927 olan turist sayıs1 2017'de 427.018 kişiye ulaşmıştır (Kültür ve Turizm Bakanlı̆̆ 1,2018 ).

$\mathrm{Bu}$ çalışmanın evreni İstanbul'a gelen İranlı turistlerden oluşturmaktadır. Araştırmada ana kütle baz alınarak örneklem yoluna gidilmiş ve tesadüfi örneklem yöntemlerinden biri olan kolayda örnekleme yöntemi seçilmiştir. Buna göre örneklem büyüklüğü aşağıdaki gibi hesaplanmıştır. 


$$
\begin{aligned}
& \text { p.q n= Örneklem büyüklüğ̈̈ } \\
& \mathrm{t}^{2} \text {. - } \quad \mathrm{N}=\text { Evren büyüklüğü } \\
& \mathrm{d}^{2} \quad \mathrm{~d}=\text { Tolerans düzeyi } \\
& \mathrm{N}=\overline{\mathrm{t}}=\text { Güven düzeyi }(\alpha=0.05 \text { için } 1,96 \text {; } \\
& \alpha=0,01 \text { için } 2,58 \text { ) } \\
& 1+\underset{N}{N} \cdot \mathrm{t}^{2} \cdot \mathrm{d}^{\mathrm{p}}-\mathrm{p}=\text { Olayın görülme sıklı̆̆ }(\mathrm{q}=1-\mathrm{p})
\end{aligned}
$$

$\mathrm{Bu}$ formüle göre $\% 95$ 'lik güven seviyesi ve $\% 5$ örnekleme hatası dikkate alınarak 378 kişi örneklem büyüklüğü olarak alınmıştır (Tanrıöğen 2009: 126). Çalışma 2018 yılı Ekim ayında başlamış, aynı yıl Kasım ayında tamamlanmıştır. Uygulama yüz yüze anket yöntemi kullanılarak gerçekleştirilmiştir. Uygulama sonucunda 400 anket geri dönüşü sağlanmıştır. 400 anketin 11 tanesi yeterli veri ve anlamlılığa sahip olmadığından değerlendirmeye alınmamıştır. Yeterli veri ve anlamlılığa sahip olmama durumu, anketlerde yöneltilen soruların tamamına cevap verilmemesi ya da okumadan rastgele işaretlemeler yapılması durumunda ortaya çıkmaktadır. Yeterli veriye sahip 389 anket araştırmaya tabii tutulmuştur.

\subsection{Veri Toplama Aracı}

Araştırmada veri toplama aracı olarak anket tekniğinden yararlanılmıştır. Söz konusu anket temel olarak iki bölümden oluşmaktadır. Birinci bölümde örneklem grubunu oluşturan bireylerin demografik ve sosyal özelliklerini belirlemek amaciyla 9 adet soruya (cinsiyet, meslek, yaş, eğitim düzeyi, medeni durum, gelir durumu, ziyaret sayısı, seyahatin amac1, kimlerle seyahat edildiği) yer verilmiştir. İkinci bölümde ise algılanan güvenlik, risk azaltma davranışı, tavsiye etme niyeti ve tekrar ziyaret etme niyeti ölçekleri yer almaktadır. 6 ifadeden oluşan algılanan güvenlik ölçeği George'un (2010), 14 ifadeden oluşan risk azaltma davranışı ölçeği Schroeder'in (2015), 2 ifadeden oluşan tavsiye etme niyeti ölçeği Hosany vd.,'nin (2015), 3 ifadeden oluşan tekrar ziyaret etme niyeti ölçeği ise Zhang, Wu ve Buhalis'in (2018) çalışmasından alınmıştır. Anket geliştirme sürecinde ilk olarak anket alanında uzman üç akademisyenin görüşüne sunulmuş olup alınan tavsiyeler doğrultusunda bazı düzeltmeler yapılmış ve anket ön deneme için hazır hale getirilmiştir. Anket formunun orijinali İngilizce olduğundan Farsça diline profesyonel tercüman tarafından çevrildikten sonra, anadili Farsça olan turist rehberlerine kontrol ettirilmiştir. Ön deneme için hazırlanan anket araştırmanın yapılmaya başlandı̆̆ gün önce hedef kitleye uygun olarak seçilen 30 kişiye uygulanmıştır. Pilot test sonucunda yapılan analizler ile ölçeklerde yer alan ifadelerin hiç birinin ölçeklerden çıkarılmasına gerek görülmemiş, ancak daha iyi anlaşılması için bazı düzenletmeler yapılarak ankete son şekli verilmiştir. Ölçeklerde yer alan maddeler beşli Likert derecelendirilmesine tabi tutulmuş olup örneklem grubunu oluşturan bireylerin her bir maddeye yönelik katılım düzeyleri

Kesinlikle Katılmiyorum=1, Katılmıyorum=2, $\mathrm{Ne}$ Katılıyorum Ne Katılmıyorum=3, Katılıyorum=4, Kesinlikle Katılıyorum $=5$ şeklinde puanlandırılmıştır.

\subsection{Verilerin Analizi}

Araştırma kapsamında katılımcılardan elde edilen veriler sosyal bilimler için geliştirilmiş bir istatistik paket programı olan SPSS 22.0 programına entegre edilmiştir. Araştırma analizlerinde istatistiksel olarak veriler tanımlayıcı ve çıkarımsal istatistik kapsamında ele alınmıştır. Araştırmada bireylerin öncelikle demografik ve sosyal özelliklerini belirleyen frekans dağılımları elde edilmiştir. Daha sonra katılımcıların algılanan güvenlik, risk azaltma davranışı, tavsiye etme niyeti ve tekrar ziyaret etme niyeti tutumlarına yönelik eğilimleri test edilmiştir. Araştırma doğrultusunda veri setine Güvenilirlik, Faktör, Korelasyon, Regresyon, OneSample T ve One-Way ANOVA testleri uygulanmıştır. Ölçeklerin güvenilirliğini test etmek amacıyla Cronbach Alfa Katsayılarına bakılmıştır. Daha sonra ölçeklerin geçerliliğini sağlamak amacıyla Faktör analizleri yapılmıştır. Korelasyon testi ile iki bağımsız değişken arasındaki doğrusal ilişki veya bir değişkenin iki veya daha çok değişkenle olan ilişkisi ile varsa bu ilişkinin derecesi tespit edilmiştir. Regresyon analizi ile bir bağımsız değişken ile bir bağımlı değişkenin ya da birden fazla bağımsız değişken ile bağımlı değişkenin arasındaki neden sonuç ilişkisi ölçülmüştür. Son olarak da katılımcıların demografik ve sosyal özellikleri ile vermiş oldukları cevaplara yönelik ölçek değişkenleri arasındaki ilişkiler test edilmiştir.

\subsection{Katılımcıların Demografik Özellikleri}

Katılımcıların demografik özelliklerine göre dağılımı Tablo 1 'de gösterilmiştir. Tablo1'e göre katılımcıların cinsiyet grupları değerlendirildiğinde \% 65,8'inin kadın, \% 34,2'sinin erkek olduğu, yaş grupları incelendiğinde \% 20,1'i 30 ile 34 yaş arasına dâhil olurken, \% 14,7'sinin 45 ile 49 yaş arasında, \% 14,4'ünün 25 ile 29 yaş arasında, \% 13,4'ünün 18 ile 24 yaş arasında, \% 12,1 ile hem 35 ile 39 yaş arasında hem de 40 ile 44 yaş arasında, \% 9,5'inin 50 ile 54 yaş arasında, \% 2,1'inin 55 ile 59 yaş arasında ve \% 1,8'inin de 60 yaş ve üzeri olduğu görülmektedir. Katılımcıların medeni durumları incelendiğinde de \% 78,9'unun evli, \% 21,1'inin ise bekar olduğu sonucuna ulaşılmaktadır. Katılımcıların eğitim durumlarına bakıldığında \% 40,1'inin üniversite mezunu, \% 37,5 'inin lise mezunu, \% 15,9'unun ortaokul mezunu, \% 3,3'ünün ilkokul mezunu ve \% 3,1'inin ise lisansüstü düzeyinde olduğu sonucuna ulaşılmıştır. Katılımcıların meslek grupları incelendiğinde, \% 30,6'sının kendi hesabına çalışan, $\%$ 30,1'inin ücretli çalışan, \% 16,2'sinin işveren, \% 12,1'inin ev hanımı, \% 7,2'sinin ev öğrenci ve \% 3,9'unun ise emekli olduğu görülmüştür. Diğer bir analiz sonucunda katılımcıların aylık ortalama gelirleri değerlendirildiğinde, \% 47'sinin yüksek gelire, \% 41,1'inin orta gelire ve \% 11,8'inin ise çok yüksek gelire sahip oldukları görülmektedir.

Tablo 1. Katılımcıların demografik özelliklerine göre dağılımı

\begin{tabular}{llcc} 
Değişkenler & & $\begin{array}{l}\text { Sayı } \\
(\mathbf{f})\end{array}$ & $\begin{array}{l}\text { Yüzde } \\
(\boldsymbol{\%})\end{array}$ \\
\hline \multirow{2}{*}{ Cinsiyet } & Kadın & 133 & 34,2 \\
& Erkek & 256 & 65,8 \\
\hline \multirow{2}{*}{ Yaş } & $18-24$ yaş & 52 & 13,4 \\
& 25-29 yaş & 56 & 14,4
\end{tabular}




\begin{tabular}{|c|c|c|c|}
\hline & 30-34 yaş & 78 & 20,1 \\
\hline & $35-39$ yaş & 47 & 12,1 \\
\hline & $40-44$ yaş & 47 & 12,1 \\
\hline & 45-49 yaş & 57 & 14,7 \\
\hline & $50-54$ yaş & 37 & 9,5 \\
\hline & $55-59$ yaş & 8 & 2,1 \\
\hline & 60 yaş ve üzeri & 7 & 1,7 \\
\hline \multirow{2}{*}{$\begin{array}{l}\text { Medeni } \\
\text { Durum }\end{array}$} & Evli & 307 & 78,9 \\
\hline & Bekar & 82 & 21,1 \\
\hline \multirow{5}{*}{ Eğitim } & İlkokul & 13 & 3,3 \\
\hline & Ortaokul & 62 & 15,9 \\
\hline & Lise & 146 & 37,5 \\
\hline & Üniversite & 156 & 40,1 \\
\hline & $\begin{array}{l}\text { Yüksek } \\
\text { Lisans/Doktora }\end{array}$ & 12 & 3,2 \\
\hline \multirow{6}{*}{ Meslek } & İşveren & 63 & 16,2 \\
\hline & Ücretli Çalışan & 117 & 30,1 \\
\hline & $\begin{array}{l}\text { Kendi Hesabına } \\
\text { Çalışan }\end{array}$ & 119 & 30,6 \\
\hline & Öğrenci & 28 & 7,2 \\
\hline & Emekli & 15 & 3,9 \\
\hline & Ev Hanımı & 47 & 12,0 \\
\hline \multirow{5}{*}{ Aylık Gelir } & Çok Düşük & 0 & 0 \\
\hline & Düşük & 0 & 0 \\
\hline & Orta & 160 & 41,1 \\
\hline & Yüksek & 183 & 47,1 \\
\hline & Çok Yüksek & 46 & 11,8 \\
\hline Toplam & & 389 & 100,0 \\
\hline
\end{tabular}

\subsection{Katılımcıların Sosyal Özellikleri}

Katılımcılara yöneltilen sorular sonucunda İstanbul'u daha önce kaç kez ziyaret ettiklerine bakıldığında, \% 46,8'inin ilk ziyareti olduğu, \% 39,3'ünün iki defa, \% 8,2'sinin üç defa ve $\% \quad 5,7$ 'sinin ise dört defa geldikleri görülmektedir. Katılımcıların seyahat amaçlarına bakıldığında da \% 61,7'sinin tatil, \% 19,3'ünün iş, \% 11,8'inin aile/arkadaş ziyareti ve \% 7,2'sinin ise sağlık amacıyla seyahat ettikleri sonucuna ulaşılmaktadır. Son olarak katılımcıların kiminle seyahat ettikleri incelendiğinde ise, \% 41,4'ünün eşi ve çocukları ile, \% 23,7' sinin eşi/sevgili ile, \% 16,2'sinin arkadaşları ile, \% 14,1'inin yalnız ve \% 4,6'sının ise ailesi ile geldiği görülmektedir.

Tablo 2. Katılımcıların Sosyal Özellikleri

\begin{tabular}{|c|c|c|c|}
\hline Değişkenler & & $\begin{array}{l}\text { Sayı } \\
(n)^{\prime}\end{array}$ & $\begin{array}{c}\text { Yüzde } \\
(\%)\end{array}$ \\
\hline \multirow{4}{*}{$\begin{array}{l}\text { Bu ziyaretiniz dahil } \\
\text { İstanbul'u daha } \\
\text { önce kaç kez } \\
\text { ziyaret ettiniz? }\end{array}$} & Bu Illk Ziyaretim & 182 & 46,8 \\
\hline & İki Defa & 153 & 39,3 \\
\hline & Üç Defa & 32 & 8,2 \\
\hline & Dört Defa & 22 & 5,7 \\
\hline \multirow{4}{*}{$\begin{array}{l}\text { Seyahat amacını } \\
\text { nedir? }\end{array}$} & Tatil & 240 & 61,7 \\
\hline & İş & 75 & 19,3 \\
\hline & Aile/Arkadaş Ziyareti & 46 & 11,8 \\
\hline & Sağlık & 28 & 7,2 \\
\hline \multirow{5}{*}{$\begin{array}{l}\text { Kiminle Seyahat } \\
\text { Ediyorsunuz? }\end{array}$} & Yalnız & 55 & 14,1 \\
\hline & Eşim/Sevgilim & 92 & 23,7 \\
\hline & Eşim ve Çocuklarım & 161 & 41,4 \\
\hline & Ailem & 18 & 4,6 \\
\hline & Arkadaşlarım & 63 & 16,2 \\
\hline Toplam & & 389 & 100,0 \\
\hline
\end{tabular}

\section{3. Ölçeklere ve Değişkenlere Yönelik Bulgular}

Araştırmanın amacına yönelik kullanılan ölçeklere ilk olarak güvenilirlik analizine tabi tutulmuştur. Güvenilirlik analizinde yer alan Cronbach's Alpha, 0,00 ile 0,40 arasında ise ölçek güvenilir değildir. Cronbach's Alpha değeri 0,40 ile 0,60 arasında yer alırsa ölçeğin güvenilirliğinin düşük olduğu, 0,60 ile 0,80 arasında yer alırsa ölçeğin oldukça güvenilir olduğu ve 0,80 ve 1,00 arasında yer alırsa ölçeğin yüksek derecede güvenilir olduğu belirtilmektedir (Kayış, 2014: 405). Bu doğrultuda araştırmanın ölçeklerine yönelik yapılan güvenilirlik analizi sonucu Algılanan Güvenlik Ölçeği'nin 6 maddelik Cronbach's Alpha katsayısı \% 60, Risk Azaltma Davranışı Ölçeği'nin 14 maddelik Cronbach's Alpha katsayısı \% 86 olarak tespit edilmiştir. Bu değerler ile Algılanan Güvenlik Ölçeği'nin oldukça güvenilir, Risk Azaltma Ölçeği'nin ise yüksek derecede güvenilir olduğunu göstermektedir.

Araştırmada amacına yönelik kullanılan ölçeklerin ve değişkenlerin ortalamaları alındığında, "Algılanan Güvenlik" ölçeğin ortalaması 3,633; "Risk Azaltma Davranışı" ölçeğinin ortalaması 3,746; "Tekrar Ziyaret Niyeti" değişkeninin ortalaması 4,357; "Tavsiye Etme Niyeti” değişkeninin ortalaması ise 4,171 olarak tespit edilmiştir.

\subsection{Algılanan Güvenlik ve Risk Azaltma Davranışına Yönelik Betimsel İstatistikler}

Tablo 3'de yer alan “Algılanan Güvenlik" ve "Risk Azaltma Davranışı" değişkenlerinin maddelerin aritmetik ortalamaları ve standart sapmalarına ilişkin değerler sunulmuştur. Değerler incelendiğinde katılımcıların "Algılanan Güvenlik" tutumlarının 5'li Likert Ölçeği derecelendirmesinde orta değer

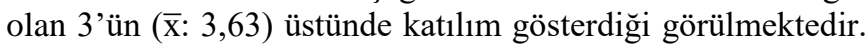
Ayrıca "Algllanan Güvenlik" değişkeni içerisinde en yüksek 
katılım oranı $(\overline{\mathrm{x}}: 4,22)$ ile "İstanbul da diğer turistik yerler kadar güvenlidir. ” ifadesine ait olduğu görülmüştür. Diğer bir değişken incelendiğinde ise, katılımcıların "Risk Azaltma Davranışı" tutumlarının ( $\overline{\mathrm{x}}: 3,74)$ ile katılım gösterdiği ve bu katılım içerisinde de en yüksek oranın $(\overline{\mathrm{x}}: 4,56)$ ile "Potansiyel bir kurban durumuna düşebileceğim durumlardan kaçınırım." ifadesinin olduğu görülmektedir.

Tablo 3. Algılanan Güvenlik ve Risk Azaltma Davranışına Yönelik Betimsel İstatistikler

\begin{tabular}{|c|c|c|c|c|c|c|c|}
\hline \multirow{3}{*}{ Maddeler } & \multicolumn{5}{|c|}{ Katılım Düzeyi } & \multirow[b]{3}{*}{$\overline{\mathrm{x}}$} & \multirow[b]{3}{*}{ SS } \\
\hline & \multirow{2}{*}{$\begin{array}{c}1 \\
\%\end{array}$} & \multirow{2}{*}{$\begin{array}{l}2 \\
\%\end{array}$} & \multirow{2}{*}{$\begin{array}{c}3 \\
\%\end{array}$} & \multirow{2}{*}{$\begin{array}{l}4 \\
\%\end{array}$} & \multirow{2}{*}{$\begin{array}{c}5 \\
\%\end{array}$} & & \\
\hline & & & & & & & \\
\hline Algılanan Güvenlik & & & & & & 3,63 & $\mathbf{0 , 5 3}$ \\
\hline 1. İstanbul güvenli bir şehirdir. & ,3 & 8,7 & 21,1 & 51,7 & 18,3 & 3,78 &, 85 \\
\hline 2. İstanbul'da bir suçun mağduru olabilirim & 9,8 & 26,5 & 43,7 & 17,2 & 2,8 & 2,76 & ,94 \\
\hline 3. İstanbul da diğer turistik yerler kadar güvenlidir. & 1,0 & 2,3 & 10,0 & 46,3 & 40,4 & 4,22 & ,79 \\
\hline 4. Çevremdekiler bana İstanbul'un tehlikeli olduğunu söyledi. & 6,2 & 49,6 & 23,9 & 20,1 &, 3 & 2,58 & ,88 \\
\hline 5. İstanbul'da kişisel güvenliğim konusunda endişelenmiştim. & 11,3 & 42,7 & 24,9 & 20,6 &, 5 & 2,56 & ,95 \\
\hline $\begin{array}{l}\text { 6. Gezmeye gelecek diğer kişilere İstanbul'da tehlikelere karşı dikkatli } \\
\text { olmalarını söyleyeceğim. }\end{array}$ & 27,0 & 34,2 & 21,9 & 15,9 & 1,0 & 2,29 & 1,06 \\
\hline Risk Azaltma Davranışı & & & & & & 3,74 & $\mathbf{0 , 6 1}$ \\
\hline 7. Sadece turistik bölgelerde dolaşırım. & 1,5 & 14,9 & 22,9 & 44,5 & 16,2 & 3,58 & ,97 \\
\hline 8. Otelimin bulunduğu bölgenin dışında gezmekten kaçınırım. & 36,2 & 37,8 & 14,7 & 8,7 & 2,6 & $\mathbf{2 , 0 3}$ & 1,04 \\
\hline $\begin{array}{l}\text { 9. Zenginlik göstergesi kabul edilebilecek şeyleri (mücevher, pahalı } \\
\text { saat, fotoğraf makinesi, pahalı cep telefonu vb.) taşımaktan kaçınırım. }\end{array}$ & - & 2,1 & 8,7 & 39,3 & 49,9 & 4,37 & ,72 \\
\hline $\begin{array}{l}\text { 10. Çevremde olup bitenlere dikkat ederim. (Çevreme karşı uyanık } \\
\text { olmaya çalışırım) }\end{array}$ & - & 4,6 & 6,2 & 37,8 & 51,4 & 4,35 & ,79 \\
\hline $\begin{array}{l}\text { 11. Potansiyel bir kurban durumuna düşebileceğim durumlardan } \\
\text { kaçınırım. }\end{array}$ & - & - & 2,6 & 38,3 & 59,1 & 4,56 &, 54 \\
\hline 12. İstanbul'u yalnız dolaşmaktan kaçınırım. & 5,7 & 19,5 & 5,7 & 35,2 & 33,9 & 3,72 & 1,27 \\
\hline $\begin{array}{l}\text { 13. Uluslararası bilinirliği olan bir banka değilse ATM'yi } \\
\text { kullanmaktan kaçınırım. }\end{array}$ & 1,3 & 19,3 & 16,5 & 28,8 & 34,2 & 3,75 & 1,15 \\
\hline 14. Sadece bildiğim duraklardan taksiye binerim. & 4,6 & 21,3 & 11,6 & 29,0 & 33,4 & 3,65 & 1,26 \\
\hline 15. Fazla miktarda nakit para taşımaktan kaçınırım. & - & - & 12,9 & 44,5 & 42,7 & 4,29 & ,68 \\
\hline 16. Dikkatlerimi üzerime çekmekten kaçınırım. & - & - & 3,3 & 54,5 & 42,2 & 4,38 &, 55 \\
\hline 17. Geceleri kendi başıma dolaşmaktan kaçınırım. & 8 & 7,7 & 18,8 & 39,1 & 33,7 & 3,97 & 95 \\
\hline 18. "Uber" gibi hizmetleri kullanmaktan kaçınırım. & 29,0 & 26,7 & 11,1 & 12,1 & 21,1 & 2,69 & $\mathbf{1 , 5 1}$ \\
\hline $\begin{array}{l}\text { 19. İstanbul'a gelemeden önce güvenlikle ilgili internetten araştırma } \\
\text { yaptım. }\end{array}$ & 3,1 & 18,3 & 11,1 & 35,7 & 31,9 & 3,75 & 1,17 \\
\hline 20. İstanbul'a gelmeden önce seyahat sigortası yaptırmayı düşündüm. & 9,8 & 18,3 & 31,6 & 13,4 & 27,0 & 3,29 & 1,30 \\
\hline
\end{tabular}

Kesinlikle Katılmıyorum=1, Katılmıyorum=2, Ne Katılıyorum Ne Katılmıyorum=3 Katılıyorum=4, Kesinlikle Katılıyorum=5

4.5. Ölçekler ve Değişkenler Arasındaki Korelasyon Bulgular1
Araştırmanın bu bölümünde, "Algılanan Güvenlik" ölçeği, "Risk Azaltma Davranışı" ölçeği, "Tekrar Ziyaret Niyeti" değişkeni ve "Tavsiye Etme Niyeti" değişkeni arasındaki ilişkiye yönelik korelasyon analizleri sunulmuştur. Korelasyon analizi, iki değişken arasındaki doğrusal ilişkiyi veya bir 
değişkenin iki veya daha çok değişken ile olan ilişkisini test etmek, varsa bu ilişkinin derecesini ölçmek için kullanılan istatistiksel bir yöntemdir. İki değişken arasında Pearson Korelasyon Katsayısı'nın 0,00-0,25 aralığında çok zayıf; 0,260,49 aralığında zayıf; $0,50-0,69$ aralığında orta; $0,70-0,89$ aralığında yüksek; 0,90-1,00 aralığında çok yüksek seviyede olduğu belirtilmektedir (Sungur, 2014:116). Yapılan analizin ilk sonucuna göre, Algılanan Güvenlik değişkeni ile Risk Azaltma Davranışı değişkeni arasında anlamlı ( $<<0,05$; $\mathrm{p}$ : ,000) fakat negatif yönlü zayıf $(\mathrm{r}:$,421) bir ilişki olduğu sonucuna ulaşılmıştır. Başka bir analiz sonucunda Algılanan Güvenlik değişkeni ile Tekrar Ziyaret Niyeti değişkeni arasında anlamlı $(\mathrm{p}<0,05 ; \mathrm{p}:, 000)$ ve pozitif yönlü zayıf (r: ,351) bir ilişki olduğu sonucu görülmüştür. Yapılan diğer bir analiz sonucuna göre, Risk Azaltma Davranışı değişkeni ile Tekrar Ziyaret Niyeti değişkeni arasındaki ilişkinin anlamlı olmadığı (p>0,05; p: ,139) sonucuna ulaşılmıştır. Ayrıca Risk Azaltma Davranışı değişkeni ile Tavsiye Etme Niyeti değişkeni arasındaki ilişkinin de anlamlı olmadığı (p>0,05; p: ,443) sonucu görülmektedir. Son olarak Tekrar Ziyaret Niyeti değişkeni ile Tavsiye Etme Niyeti değişkeni arasında anlamlı (p<0,05; p: ,022) ve pozitif yönlü çok zayıf $(\mathrm{r}:, 116)$ bir ilişki olduğu sonucuna ulaşılmıştır.

Tablo 4. Algılanan Güvenlik, Risk Azaltma Davranışı, Tekrar Ziyaret Niyeti ve Tavsiye Etme Niyeti Değişkenleri Arasındaki İlişkiye Yönelik Korelasyon Analizi Sonucu

\begin{tabular}{|c|c|c|c|c|c|}
\hline & & 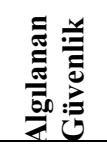 & 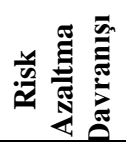 & 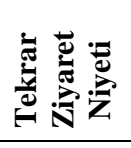 & 空导 \\
\hline \multirow{2}{*}{ Algılanan Güvenlik } & Korelasyon Katsayası & 1,000 &,$- \mathbf{4 2 1} 1^{* *}$ &, $351^{* *}$ & ,046 \\
\hline & Sig. (2-tailed) & - &, 000 &, 000 &, 367 \\
\hline \multirow{2}{*}{$\begin{array}{c}\text { Risk Azaltma } \\
\text { Davranışı }\end{array}$} & Korelasyon Katsayası &,$- 421^{* *}$ & 1,000 &,- 075 & ,039 \\
\hline & Sig. (2-tailed) &, 000 & - &, 139 & ,443 \\
\hline \multirow{2}{*}{$\begin{array}{c}\text { Tekrar Ziyaret } \\
\text { Niyeti }\end{array}$} & Korelasyon Katsayası &, $351^{* *}$ &,- 075 & 1,000 &, $\mathbf{1 1 6}^{* *}$ \\
\hline & Sig. (2-tailed) &, 000 &, 139 & - & ,022 \\
\hline \multirow{2}{*}{ Tavsiye Etme Niyeti } & Korelasyon Katsayası & ,046 & ,039 &, $\mathbf{1 1 6}^{* *}$ & 1,000 \\
\hline & Sig. (2-tailed) & ,367 & 443 & ,022 & - \\
\hline
\end{tabular}

${ }^{* * *} \mathrm{p}<0,05 \mathrm{~N}=(389)$

\subsection{Araştırmanın Hipotezlerine Yönelik Bulgular}

Araştırmanın bu bölümünde, katılımcıların vermiş oldukları cevaplar doğrultusunda "Algllanan Güvenlik" değişkeni ile "Risk Azaltma Davranışı", "Tekrar Ziyaret Niyeti" ve "Tavsiye Etme Niyeti” değişkenleri arasındaki etkiye yönelik regresyon analizleri sunulmuştur. Regresyon analizi, bir bağımsız değişken ile bir bağımlı değişkenin ya da birden fazla bağımsız değişken ile bir bağımlı değişkenin arasındaki neden sonuç ilişkisini ölçmek için kullanılan istatistiksel bir yöntemdir.

Tablo 5. Algılanan Güvenlik Değişkeni ile Risk Azaltma Davranışı, Tekrar Ziyaret Niyeti ve Tavsiye Etme Niyeti Değişkenlerine Yönelik Regresyon Analiz Sonuçları

\begin{tabular}{|c|c|c|c|c|c|c|c|}
\hline Bağımsız Değişken & Bağımlı Değişken & $\mathbf{R}$ & $\mathbf{R}^{2}$ & B & Beta & Sig. & $\mathbf{F}$ \\
\hline \multirow{3}{*}{ Algılanan Güvenlik } & Risk Azaltma Davranışı & 0,463 & 0,215 & ,424 &, $463^{*}$ & ,000 & 11,378 \\
\hline & Tekrar Ziyaret Niyeti & 0,133 & 0,018 & ,085 & $133^{*}$ & ,006 & 7,502 \\
\hline & Tavsiye Etme Niyeti & 0,189 & 0,036 & 149 &, $189^{*}$ & ,000 & 15,338 \\
\hline
\end{tabular}

${ }^{*} \mathrm{p}<0,05$

H1: Katılımcıların algıladıkları güvenlik risk azaltma davranışlarını etkilemektedir.

Yapılan Regresyon Analizi sonucunda, katılımcıların Algılanan Güvenlikleri ile Risk Azaltma Davranışları arasındaki etkiye yönelik ilişki değerlerinin anlamlı ( $\mathrm{p}>0,05$; $\mathrm{p}:$,000) ve pozitif yönlü olduğu sonucuna ulaşılmıştır. Bu sonuç, oluşturulan H1 hipotezinin desteklendiğini göstermektedir.

H2: Katılımcıların algıladıkları güvenlik tekrar ziyaret niyetlerini etkilemektedir.
Başka bir Regresyon Analizi sonucunda, katılımcıların Algllanan Güvenlikleri ile Tekrar Ziyaret Niyetleri arasındaki etkiye yönelik ilişki değerlerinin anlamlı (p>0,05; p: ,006) ve pozitif yönlü olduğu sonucuna ulaşılmıştır. $\mathrm{Bu}$ sonuç, oluşturulan $\mathbf{H 2}$ hipotezinin desteklendiğini göstermektedir.

\section{H3: Katılımcıların algıladıkları güvenlik tavsiye etme niyetlerini etkilemektedir.}

Son olarak yapilan Regresyon Analizi sonucunda, katılımciların Algllanan Güvenlikleri ile Tavsiye Etme Niyetleri arasındaki etkiye yönelik ilişki değerlerinin anlamlı 
(p>0,05; p: ,000) ve pozitif yönlü olduğu sonucuna ulaşılmıştır. $\mathrm{Bu}$ sonuç, oluşturulan $\mathbf{H 3}$ hipotezinin desteklendiğini göstermektedir. Ayrıca Regresyon modeline ait $\mathrm{R}^{2}$ değerleri incelendiğinde, Algllanan Güvenlik değişkeni Risk Azaltma Davranışı değişkeninin \% 11' ini, Tekrar Ziyaret Niyeti değişkeninin \% 6'sını ve Tavsiye Etme Niyeti değişkeninin ise \% 15'ini açıkladığı görülmektedir.

\subsection{Tanımlayıcı Değişkenlere Göre Farklılık Analizi Sonuçları}

Değişkenlere yönelik yapılan Kolmogorov-Smirnov testi sonucunda verilerin $\mathrm{p}>0,050$ 'nin üstünde olduğu ve normal dağılım gösterdiği bulgulanmıştır. $\mathrm{Bu}$ nedenle değişkenler arasındaki anlamlılık değerlerini ölçmek için One-Sample T ve One-Way ANOVA testlerine analiz için ihtiyaç duyulmuştur. Çalışmada katılımcıların "Algllanan Güvenlik" ve "Risk
Azaltma Davranışı" demografik özelliklere göre karşılaştırılmış olup cinsiyete göre anlamlı farklılık tespit edilmemiştir $(p>0,05)$. Anlamlı farklılıklar tespit edilen $(p<0,05)$, yaş, medeni durum, eğitim, meslek, gelir, kaç kez ziyaret edildiği ve seyahatin amacına göre karşılaştırmalar Tablo 6'da sunulmuştur. Yaşla ilgili olarak ortalamalar incelendiğinde "Algllanan Güvenlik" tutumunun en fazla 4549 yaş, "Risk Azaltma Davranışı" tutumunun en fazla 60 yaş ve üzeri katılımcılarda olduğu görülmektedir. Medeni durumda "Algllanan Güvenlik" tutumunun en fazla bekar katılımcılarda, "Risk Azaltma Davranışı" tutumunun en fazla evli katılımcılarda olduğu görülmektedir. Eğitim durumuyla ilgili "Algllanan Güvenlik" tutumunun en yüksek lisans/doktora mezunu katılımcilarda, "Risk Azaltma Davranışı" tutumunun en fazla ilkokul mezunu katılımcılarda olduğu görülmektedir.

Tablo 6. Katılımcıların Tanımlayıcı Değişkenleri ile Güvenlik Tutumları Arasındaki İlişkiye Yönelik One-Sample T ve One-Way ANOVA Test Sonuçları

\begin{tabular}{|c|c|c|}
\hline Değişkenler & $\begin{array}{l}\text { Algılanan } \\
\text { Güvenlik }\end{array}$ & Risk Azaltma Davranışı \\
\hline Cinsiyet & $\mathrm{F}:, 452$ & $F: 1,324$ \\
\hline Kadın & 3,30 & 4,16 \\
\hline Erkek & 3,80 & 3,53 \\
\hline Yaş & $F: 10,139^{* *}$ & $\mathrm{~F}: 4,349^{* *}$ \\
\hline $18-24$ yaş & 3,30 & 3,88 \\
\hline $25-29$ yaş & 3,44 & 3,97 \\
\hline 30-34 yaş & 3,74 & 3,59 \\
\hline 35-39 yaş & 3,73 & 3,76 \\
\hline $40-44$ yaş & 3,61 & 3,70 \\
\hline $45-49$ yaş & 3,91 & 3,81 \\
\hline $50-54$ yaş & 3,82 & 3,36 \\
\hline 55-59 yaş & 3,16 & 3,81 \\
\hline 60 yaş ve üzeri & 3,02 & 4,14 \\
\hline Medeni Durum & $F: 46,445^{* *}$ & $\mathrm{~F}: 4,122^{* *}$ \\
\hline Evli & 3,59 & 3,82 \\
\hline Bekar & 3,76 & 3,45 \\
\hline Eğitim Durumu & $\mathrm{F}: \mathbf{8 , 3 5 2 ^ { * * }}$ & $\mathrm{F}: \mathbf{2 , 8 9 8 ^ { * * }}$ \\
\hline İlkokul & 3,02 & 4,02 \\
\hline Ortaokul & 3,51 & 3,81 \\
\hline Lise & 3,61 & 3,81 \\
\hline Üniversite & 3,71 & 3,64 \\
\hline Yüksek Lisans/Doktora & 4,05 & 3,49 \\
\hline Meslek & $\mathrm{F}: 28,411^{* *}$ & $\mathrm{~F}: 18,684^{* *}$ \\
\hline İşveren & 4,05 & 3,39 \\
\hline Ücretli Çalışan & 3,69 & 3,75 \\
\hline Kendi Hesabına Çalışan & 3,67 & 3,72 \\
\hline Öğrenci & 3,39 & 3,39 \\
\hline Emekli & 3,22 & 4,19 \\
\hline Ev Hanımı & 3,09 & 4,30 \\
\hline Aylık Ortalama Gelir & $\mathrm{F}: 14,394^{* *}$ & $\mathrm{~F}: 12,623^{* *}$ \\
\hline Orta & 3,53 & 3,65 \\
\hline
\end{tabular}




\begin{tabular}{llr} 
Yüksek & 3,62 & 3,89 \\
Çok Yüksek & 3,99 & 3,46 \\
\hline
\end{tabular}

** $\mathrm{p}<0,05$

Meslek de ise "Algllanan Güvenlik" tutumunun en fazla işveren olan katılımcılarda, "Risk Azaltma Davranışı" tutumunun en fazla ev hanımı olan katılımcılarda olduğu görülmektedir. Aylık ortalama gelir bazında "Algllanan
Güvenlik" tutumunun en fazla çok yüksek gelire sahip olan katılımcilarda, "Risk Azaltma Davranışı" tutumunun en fazla yüksek gelire sahip olan katılımcılarda olduğu görülmektedir.

Tablo 6. Devamı

\begin{tabular}{|c|c|c|}
\hline Değişkenler & $\begin{array}{l}\text { Algılanan } \\
\text { Güvenlik }\end{array}$ & Risk Azaltma Davranış \\
\hline İstanbul'un kaç kez ziyaret edildiği & $\mathrm{F}: 15,602^{* *}$ & $\mathrm{~F}: 36,681^{* *}$ \\
\hline Bu ilk Ziyaretim & 3,55 & 3,85 \\
\hline İki Defa & 3,58 & 3,85 \\
\hline Üç Defa & 3,82 & 3,26 \\
\hline Dört Defa & 4,28 & 2,75 \\
\hline Seyahatin amacı & $\mathrm{F}: \mathbf{1 2 , 2 8 1 ^ { * * }}$ & $\mathrm{F}: 17,260^{* *}$ \\
\hline Tatil & 3,52 & 3,84 \\
\hline İş & 3,86 & 3,42 \\
\hline Aile/Arkadaş Ziyareti & 3,62 & 3,51 \\
\hline Sağlık & 3,94 & 4,18 \\
\hline Kiminle Seyahat Edildiği & $\mathrm{F}: 14,240^{* *}$ & $\mathrm{~F}: 42,560^{* *}$ \\
\hline Yalnız & 4,04 & 2,99 \\
\hline Eşim/Sevgilim & 3,67 & 3,79 \\
\hline Eşim ve Çocuklarım & 3,47 & 4,00 \\
\hline Ailem & 3,54 & 4,06 \\
\hline Arkadaşlarım & 3,61 & 3,58 \\
\hline
\end{tabular}

** $\mathrm{p}<0,05$

"İstanbul'un kaç kez ziyaret edildiği" ile ilgili olarak "Algllanan Güvenlik” tutumunun en fazla İstanbul'a dört defa gelen katılımcilarda ve "Risk Azaltma Davranışı” tutumunun ise en fazla İstanbul'a bir defa ile iki defa gelen katılımcılarda olduğu görülmektedir. Katılımcıların güvenlik tutumlarının "seyahatin amacı" bazında "Algllanan Güvenlik" ile "Risk Azaltma Davranışı” tutumunun en fazla sağlık amaciyla gelen katılımcılarda olduğu görülmektedir. Son olarak "kiminle seyahat edildiği" ile ilgili olarak "Algllanan Güvenlik" tutumunun en fazla seyahate yalnız çıkan katılımcılarda, "Risk Azaltma Davranışı" tutumunun en fazla seyahate ailesi ile çıkan katılımcılarda olduğu görülmektedir.

\section{Tartışma, Sonuç ve Öneriler}

Turizm ve güvenlik kavramı birbiriyle sıkı ilişki içindedir. Turist davranışı ve sonuç olarak, destinasyonlar, güvenlik algıs1 ile güvenlik ve risk yönetiminden derinden etkilenmektedirler (Hall vd., 2004). Yabancı turistlere kaşı işlenen suçlar medya aracılığı ile yayılmakta ve kısa sürede yabanc1 turist sayisinda azalmaya neden olmaktadır (Kapuscinski ve Richards, 2016) ayrica destinasyonun, bölgenin ve hatta ülkenin imajını zedelemektedir (Batra, 2008). Kendilerini güvende hissetmeyen turistler de tatil deneyimlerini olumsuz etkileyecek şekilde risk azaltma davranışı olarak adlandırılan kişisel güvenlik önemleri alabilmektedirler. Bu nedenle turistler için güvenli bir ortam oluşturmak, kendilerini güvende hissetmelerini sağlamak oldukça önemlidir. Dolayısıyla turistlerin güvenlik algılarını ve bu algı sonucunda gösterdikleri risk azaltıcı davranışları belirlemek gerekmektedir. Buradan yola çıkarak çalışmada güvenlik algısının risk azaltma davranışı üzerindeki etkisi, turistlerin güvenlik algısının tekrar ziyaret etme ve tavsiye etme niyeti üzerindeki etkisini, sosyo-demografik özellikler ile güvenlik algısı ve risk azaltma davranışı arasındaki ilişkiyi incelemek amaçlanmıştır. Aynı zamanda İranlı turistlerin İstanbul'la ilgili güvenlik algılarının belirlenmesine çalışılmıştır.

Yapılan çalışma, İstanbul'a gelen İranlı turistlerin İstanbul ile ilgili güvenlik algılarının olumlu olduğunu göstermektedir. Araştırmadan elde edilen bulgulara göre en çok "İstanbul'da diğer turistik yerler kadar güvenlidir" ifadesine, ikinci olarak da "İstanbul güvenli bir şehirdir" ifadesine katılım 
gösterilmiștir. İranlı turistlerin İstanbul'u diğer turistik yerler kadar güvenli buldukları görülmektedir. Söz konusu algının Avrupalı turistlerden daha olumlu olması coğrafi, kültürel, dini vb. yakınlığa bağlanabilir.

Çalışmada ayrıca İstanbul'u ziyaret eden İranlı turistlerin risk azaltma davranışıyla ilgili önemli sonuçlar elde edilmiştir. İfadelere gösterilen katılımlar turistlerin potansiyel bir kurban durumuna düşecekleri durumlardan kaçındıkları, dikkatleri üzerlerine çekmemeye çalıştıklarını ve otellerinin bulunduğu bölge dışına çıktıkları ancak daha çok turistik bölgelerde dolaştıklarını göstermektedir. Ayrıca zenginlik gösterisi kabul edilen pahalı takılar, eşyalar ile fazla nakit para taşımayı tercih etmedikleri görülmektedir. Gece daha az dişarıya çıkma eğilimi içinde oldukları da belirlenmiştir. Bununla birlikte taksi hizmeti veren Uber'i yaygın kullandıkları, her duraktan taksiye binmekte bir mahsur görmedikleri tespit edilmiştir. Turistlerin İstanbul'un güvenli bir şehir olduğuna dair algılarının olumlu olmasına karşın risk azaltma davranışlarında turist olmalarının getirdiği bazı dezavantajların üstesinden gelebilmek amacıyla daha dikkatli oldukları görülmüştür. Literatürde farklı kültür, dil engelleri, evlerinden çok uzakta olmaları gibi turist olmalarından kaynaklı suç mağduru olma risklerinin yüksek olduğunu belirten çalışmalar (Hall vd., 2004; Batra, 2008; Monk vd., 2010; Khajuria ve Khanna, 2014; Rezaei vd., 2018), İranlı turistlerin İstanbul'a ait risk algısının olumlu olmasına karşın oldukça "temkinli" olmalarını açıklamaktadır.

Çalışmanın ortaya çıkan bulgularından bir diğeri ise algılanan güvenliğin risk azaltma davranışı üzerinde etkili olduğudur. Algılanan güvenlik seviyesi düştükçe risk azaltma davranışları artmaktadır. Bulgular turistlerin gittikleri destinasyonu güvensiz bulduklarında, kendilerini güvene almak amacıyla daha temkinli davrandıklarını ortaya koyan daha önceki çalışmalar (Barker vd., 2003; George, 2010; Woosnam vd., 2015) ile örtüşmektedir. Ayrıca, kendilerini güvende hissetmeyen turistlerin destinasyonu tekrar ziyaretlerinin ve destinasyonu başkalarına tavsiye etme ihtimallerinin çok düşük olduğunu bulgulamış olan çalışmalara (Mansfeld ve Pizam, 2006; George, 2010; Woosnam vd., 2015) paralele olarak bu çalışmada da güvenlik algısının tavsiye etme ve tekrar ziyaret etme davranışını etkilediği görülmüştür.

Çalışmanın dikkat çekici bir sonucu da algılanan güvenlik ve risk azaltma davranışında cinsiyet farkı olmamasıdır. Algılanan güvenliğin cinsiyete göre farklılaştığını, özellikle kadınlarda daha yüksek olduğunu belirten çalışmaların (Barker, Page ve Meyer, 2003; George, 2010; Rezaei vd., 2018) aksine bu çalışmada algılana güvenlik cinsiyete göre farklılık göstermemiştir. İranlı kadınlar daha önce de belirtildiği gibi kendilerini İstanbul'da yabancılık çekmedikleri, ülkelerinde olduğu kadar rahat oldukları söylenebilir. Kadın olmalarından dolayı fazladan bir tehdide açık olmadıklarını düşünmekteler. Bununla birlikte, algılanan güvenliğin en yüksek olduğu gruplar 45-49 yaş aralığında bekar iyi eğitimli yüksek gelir seviyesine sahip tatile yalnız çıkanlardır. George'un (2010) çalışmasında da benzer yaş aralığında güvenlik algısı yüksek bulgulanmıştır. İstanbul'a ailesi, eşi ve çocuklarıyla gelenler de risk azaltma davranışına önem verdikleri görülmüştür. Yanlarında çocukların olması yetişkinleri daha dikkatli olmaya sevk ettiği düşünülebilir. İstanbul'a sık sık gelen turistlerin algıladıkları güvenlik yüksek, risk azaltma davranışları ise düşük çıkmıştır. Ancak 1 veya 2 defa gelenlerde algılanan güvenlik daha düşük ve risk azaltma davranışlarının daha yüksek olduğu görülmüştür.

Turistlerin güvenlik algılarını yükseltmek ve buna bağlı olarak risk azaltma davranışlarını makul bir düzeye çekmek amacıyla kolluk kuvvetleri ve turizm endüstrisi, suçları önleme konusunda koordinasyon içinde hareket etmelidirler. Güvenlik algısının yükseltilmesiyle risk azaltma davranışının makul düzeye indirilmesi sonucunda bazı faydalar elde edilebilmektedir. Turistler gece daha çok dişarıya çıkamaya başlayabilir ve turistik bölgelerden farklı bölgelere gidebilirler. Böylece eğlence yerlerinin daha çok iş yapma olasılıkları ortaya çıkmış olur ve turistik bölge dışındaki bölgelerde turistlerin harcamaları oteller ve turistik tesislerden farklı yerlere dağılmış olur.

Diğer önemli bir konu ise turistlerin güvenlikleriyle ilgili olarak uyarılmaları ve bilgilendirilmeleridir. Literatürde bazı çalışmalar (Batra, 2008; Wichasin, ve Doungphummes, 2012; Bayhan ve Ünlüönen, 2016; An, 2016) alınan önemlerin görünür olmasının ve yoğun bilgilendirmenin güvenlik duygusunu yükselteceğini, bazı çalışmalar (Aras, 2017) ise görünür olmasının endişe uyandıracağını belirtmiştir. $\mathrm{Bu}$ noktada dikkat edilmesi gereken nokta turistler güvenlikleri konusunda uyarılıp bilgilendirilirken endişeye kapılmalarına yol açacak ve rahatça dolaşmalarına, etkinliklere katılmalarına engel olacak bir durumun oluşmamasına dikkat edilmelidir. Zira turistler için risklere karşı korunacağından şüphe duymamak değil, risklerle yüzleşmeyeceğinden emin olmak daha önemlidir (Aras, 2017). Bununla birlikte turistler güvenlikleriyle ilgili yardıma ihtiyaçları olduğunda bu yardımı kolayca alabileceklerini de hissetmelidirler. İstanbul'u ziyaret eden İranlı turistler özelinde bazı önemli bilgilendirmeler Farsça yazılabilir, İstanbul'un en yoğun turistik merkezlerinde bu dili konuşan, olası bir suçu önlemek için değil de ihtiyaç duyulan herhangi bir konuda yardımcı olmak amacıyla orada bulunan bir görevli gibi davranan turizm polislerinin varlığı turistleri rahatlatabilir, güvenlik duygularını yükseltebilir.

Çalışmanın sonuçları da teyit etmektedir ki, turizm endüstrisi güvenliği sağladığı ölçüde rağbet görecek ve gelişecektir. Turistlerin emniyeti ve güvenliğini sağlamak için önlemler almak ve uygulamak turizm destinasyonun geleceği ve tekrar ziyareti açısından son derece önemlidir (George ve Swart, 2012; Mansfeld ve Pizam, 2006). Yabancı turistlere karş1 işlenen suçlar yoğun bir şekilde kamuoyuna duyurulmakta ve yabancı ziyaretçi sayısının azalmasına ve ulusal ve uluslararası destinasyon imajının zedelenmesine neden olmaktadır (Batra, 2008).

Çalışmada bazı kısıtlar mevcuttur. Çalışma, sağlık, hastalık, kazalar, terörizm ve doğal tehlikelerle ilgili daha geniş güvenlik hususlarını kapsamamaktadır. Ayrıca çalışma İstanbul'da İranlı turistlerle yapılmıştır. Gelecek çalışmalar farklı milletlerden turistlerle yapılabilir, böylece karşılaştırma yapma olasılığ 1 elde edilmiş olur.

\section{Kaynakça}

An, S. (2016). Examining the Relationships Among Perceived Risk, Attitude and Intention to Travel to Destinations Along the US-Mexico Border (Doctoral dissertation), A\&M University, Texas. 
Aras, H. (2017). Türkiye'de Turizm Güvenliği Sorunu, Hitit Üniversitesi. Sosyal Bilimler Enstitüsü Dergisi, 10(1), 585610.

Ateşoğlu, İ., \& Türker, A. (2014). Tatil Yeri Seçiminde Ülke İmajının Turistin Risk Algısı Üzerine Etkisi, Uluslararası Alanya Issletme Fakültesi Dergisi, 6(2), 9-28.

Aktaş Polat, S., \& Polat, S. (2014), "Yabancı Turistlerin Müşteki 'Mağdur' Olarak Müdahil Oldukları Asayiş Suç Türlerinin Belirlenmesine Yönelik Bir Araştırma", Seyahat ve Otel İ̧letmeciliği Dergisi, 11(1), 38-57.

Barker, M., Page, S. J., \& Meyer, D. (2003). Urban visitor perceptions of safety during a special event. Journal of Travel Research, 41(4), 355-361.

Batra, A. (2008). Foreign tourists' perception towards personal safety and potential crime while visiting Bangkok. Anatolia, 19(1), 89-101.

Bayhan, İ., \& Ünlüönen, K. (2016). Turist Tercihlerinde Güvenliğe İlişkin Tutumlarının Etkisi: Bir Alan Araştırması. Elektronik Sosyal Bilimler Dergisi, 15(56), 1-20.

Chew, E. Y. T., \& Jahari, S. A. (2014). Destination image as a mediator between perceived risks and revisit intention: A case of post-disaster Japan. Tourism Management, 40, 382-393.

Demirci, Y. (2018). Terörün İstanbul Turizmine Etkileri. (Yayımlanmamış yüksek lisans tezi). İstanbul Ticaret Üniversitesi, Sosyal Bilimler Enstitüsü, Turizm İşletmeciliği, İstanbul.

George, R. (2010). Visitor perceptions of crime-safety and attitudes towards risk: The case of Table Mountain National Park, Cape Town. Tourism Management, 31(6), 806-815.

George, R., \& Booyens, I. (2014). Township tourism demand: Tourists' perceptions of safety and security. In Urban Forum 25(4), 449-467). Springer Netherlands.

George, R., \& Swart, K. (2012). International tourists' perceptions of crime-risk and their future travel intentions during the 2010 FIFA World Cup ${ }^{\mathrm{TM}}$ in South Africa. Journal of Sport \& Tourism, 17(3), 201-223.

Hall, C. M., Timothy, D. J., \& Duval, D. T. (2004). Security and tourism: towards a new understanding?. Journal of Travel \& Tourism Marketing, 15(2-3), 1-18.

Hosany, S., Prayag, G., Deesilatham, S., Caussevic, S. ve Odeh, K. (2015). Measuring tourists' emotional experiences: Further validation of the destination emotion scale. Journal of Travel Research, 54(4), 482-495

Irvine, W., \& Anderson, A. R. (2006). The effect of disaster on peripheral tourism places and the disaffection of prospective visitors. In Y. Mansfeld, \& A. Pizam (Eds.), Tourism, Security \& Safety: From theory to practice (pp. 169-186). Oxford:Butterworth-Heinemann.

İstanbul Kültür Çalıştayı (2018). İstanbullu Olmak: Şehir, Kimlik, Şuur. İstanbul İl Kültür ve Turizm Müdürlüğü Yayınları.
Kapuscinski, G., \& Richards, B. (2016). News framing effects on destination risk perception. Tourism Management, 57, 234244.

Kayış, A., (2014). Güvenilirlik Analizi, Editör: Şeref Kalaycı, SPSS Uygulamalı Çok Değişkenli İstatistik Teknikleri (ss: 401-419), 6. Baskı, Ankara, Asil Yayın Dağıtım.

Khajuria, S., \& Khanna, S. (2014). Tourism risks and crimes at pilgrimage destinations-A case study of Shri Mata Vishnu Devi. International Journal of Event Management Research, 8(1), 77-93.

Kültür Turizm Bakanlığı. (2018). İstanbul İl Kültür ve Turizm Müdürlüğü. （Erişim: 06.12.2018), http://www.istanbulkulturturizm.gov.tr/TR-187624/temmuz2017-istanbul-turizm-istatistikleri-yayinlanmist-.html

Mansfeld, Y., \& Pizam, A. (2006). Tourism, security and safety: From theory to practice. New York: Routledge.

Maslow, A. H. (1970). Motivation and personality (Second Edition) New York: Harper \& Row. Publishers, US.

Monk, K. M., Heinonen, J. A., \& Eck, J. E. (2010). ProblemOriented Guides for Police Problem-Specific Guides Series No. 59.

Pearce, P. L., \& Lee, U. I. (2005). Developing the Travel Career Approach to Tourist Motivation. Journal of Travel Research, 43(3), 226-237.

Rezaei, S., Shahijan, M. K., Valaei, N., Rahimi, R., \& Ismail, W. K. W. (2018). Experienced international business traveller's behaviour in Iran: A partial least squares path modelling analysis. Tourism and Hospitality Research, 18(2), 163-190.

Rittichainuwat, B. N., \& Chakraborty, G. (2012). Perceptions of importance and what safety is enough. Journal of Business Research, 65(1), 42-50.

Ryan, C. (1993). Crime, violence, terrorism and tourism: an accidental or intrinsic relationship?. Tourism Management, 14(3), 173-183.

Schroeder, A., \& Pennington-Gray, L. (2014). Perceptions of crime at the Olympic Games: What role does media, travel advisories, and social media play?. Journal of Vacation Marketing, 20(3), 225-237.

Schroeder, A. (2015), Revisiting travel risk after three decades of study: the role of perceive risk, perceived efficacy, and risk reduction behaviors, unpublished doctoral dissertation, University of Florida, Gainesville, FL.

Seabra, C., Abrantes, J. L., \& Kastenholz, E. (2014). The influence of terrorism risk perception on purchase involvement and safety concern of international travellers. Journal of Marketing Management, 30(9-10), 874-903.

Seçilmiş, C., \& Ünlüönen, K. (2009). İstanbul'u Ziyaret Eden Turistlerin Güvenlik Algılamaları Üzerine Bir Araştırma. İşletme Araştırmaları Dergisi, 1(1), 65-84.

Sungur, O. (2014). Korelasyon Analizi, Editör: Şeref Kalaycı, SPSS Uygulamalı Çok Değişkenli İstatistik Teknikleri (ss: 116), 6. Baskı, Ankara, Asil Yayın Dağıtım. 
Sönmez, S. F., \& Graefe, A. R. (1998a). Influence of Terrorism Risk on Foreign Tourism Decisions. Annals of Tourism Research, 25(1), 112-144.

Sönmez, S. F., \& Graefe, A. R. (1998b). Determining Future Travel Behavior from Past Travel Experience and Perceptions of Risk and Safety. Journal of Travel Research, 37, 171-177.

Sönmez, S. F., \& Sirakaya, E. (2002). A Distorted Destination Image? The Case of Turkey. Journal of Travel Research, 41, 185-196.

Sönmez, S. F., Apostolopoulos, Y, \& Tarlow, P. (1999). Tourism in Crisis: Managing the Effects of Terrorism. Journal of Travel Research, 38, 13-18

Tanrı̈ğen, A. (2009). Bilimsel Araştırma Yöntemleri, Ankara, Anı Yayıncilık.

Taşc1, A. D., \& Gartner, W. C. (2007). Destination image and its functional relationships. Journal of Ttravel Research, 45(4), 413-425.

Türk Dil Kurumu (TDK). (2018). Güncel Türkçe Sözlük. (Erişim: 02.09.2018) http://www.tdk.gov.tr/index.php?option=com_gts\&arama=gt s\&guid=TDK.GTS.5c0cf3df6ce6e 1.61007618
UNWTO (1996). Tourist Safety and Security: Practical Measures for Destinations. (Erişim: 04.01.2019), http://www2.unwto.org/publication/tourist-safety-andsecurity-practical-measures-destinations

Wichasin, P., \& Doungphummes, N. (2012). A comparative study of international tourists' safety needs and Thai tourist polices' perception towards international tourists' safety needs. World Academy of Science, Engineering and Technology, 67(1), 1372-1378.

Woosnam, K. M., Shafer, C. S., Scott, D., \& Timothy, D. J. (2015). Tourists' perceived safety through emotional solidarity with residents in two Mexico-United States border regions. Tourism Management, 46, 263-273.

Yeşiltaş, M., Öztürk, İ., \& Türkmen, F. (2008). Terör faaliyetlerinin turizm sektörüne etkilerinin çözüm önerileri perspektifinde değerlendirilmesi. Sosyal Bilimler Dergisi, 10(1), 175-189.

Zhang, H., Wu, Y., \& Buhalis, D. (2018). A model of perceived image, memorable tourism experiences and revisit intention. Journal Of Destination Marketing \& Management, 8(1), 326-336. 